\title{
'The Voices of the People Involved': Red, Representation and Histories of Labour
}

\author{
LESLIE WITZ \\ Department of History, University of the Western Cape
}

The installation artwork Red by Simon Gush (with his collaborators James Cairns and Mokotjo Mohulo) evokes two senses of representation. One is of symbolism, meaning, visual strategies, juxtapositions, silences and so on. The other appears as the authority to speak on behalf of the views of an individual or an assemblage such as 'the workers', 'the community' or 'the people'. In this article I employ this double sense of the term to consider how the voice of the worker has been deployed in the production of South African labour histories. I do this through examining what was arguably the major labour history publication in South Africa in the 1970s and 1980s, the South African Labour Bulletin. It devoted a large part of its November 1990 issue to the strike and sleep-in at the Mercedes-Benz plant in East London in that year, the same set of events that Gush drew upon over twenty years later. I then turn to the installation Red itself, originally exhibited in 2014 at the Goethe Institute in Johannesburg and the following year at the Ann Bryant Gallery in East London. In Red, events were made into history through voices and images on film and the fabrication of artefacts for display: 'strike uniforms', a 'Mandela car' and 'sleep-in strike beds'. The latter were presented in the installation's publicity as speculative reconstructions and counterposed with interviews in the film component that were depicted as 'the voices of the people involved' from management and labour. Instead I argue for seeing these both a speculative reconstructions. Linking this to the spatialising technologies of museums I examine how the Lwandle Migrant Labour Museum in Cape Town and the Workers Museum in Johannesburg, evoke voice and words in their depictions of migrant labour. Locating the Labour Bulletin and these museums alongside Red provides an opportunity to think of alternative ways that labour histories may be produced in both the academy and the public domain.

For 65 minutes into the film by Simon Gush and James Cairns that forms part of the installation Red (2014), Goodman Lucwaba does not utter a single word. He is seated at what appears to be a boardroom table (there are two small model Mercedes-Benzes in the background) together with Sydney Nyengane and Andile Ntsonkota as they talk about worker militancy, the building of a red Mercedes for Nelson Mandela, and of the sleep-in by the workers at the Mercedes-Benz factory in East London, South Africa in 1990. His mobile phone rings. He looks but does not answer it. Sometimes he smiles. Sometimes his head and face move as if to indicate agreement. There even appears to be a lack of interest as if he wants the interview to end. And then after 65 minutes he says: 'The material that the people were actually using when there was a sleep-in was from this building, that was the seat assembly material.' That is all he says 
in the entire film that runs for just over 80 minutes. This is in stark contrast to all the others who appear and give lengthy, eloquent renditions in English of these events. Of course what we as viewers do not know is that in the making of the film he might have spoken very much more. ${ }^{1}$ But that is beside the point. After his hugely long silence, his brief intervention of a single utterance emphatically interrupts the account.

In contrast to the almost muted voice of Goodman Lucwaba, the former National Union of Metal Workers of South Africa (NUMSA) constituency shop steward at Mercedes, Thembalethu Fikizolo, dominates Red. For the first ten minutes of the film, even before the title appears, it is only his story that we hear and see. He sits in a swivel chair at a table in a room with only a white projection screen as backdrop. No one else has the floor to themselves for such a long period as he tells about internecine trade union conflicts between South African Allied Workers Union (SAAWU) and NUMSA members at the plant, sometimes seeing himself as part of the events (using 'we') but inadvertently slipping into a present outsider perspective (as 'they)'. After this he appears alongside Philip Groom in a much more informal outdoor setting where they are in conversation about shop floor relations and the initiative to build and present a Mercedes to Mandela. Although he says much less in this part of the film he does respond verbally and through physical gestures to Groom's also extensive narrative. Then in the final 30 minutes, devoted to the sleep-in, we are back with the office interview and Fikizolo is given substantial airtime as he tries to explain what he calls the 'personal dynamics' that led to the divisions in the workforce at Mercedes-Benz South Africa (MBSA). If anything, the voice of Red is that of Fikizolo.

Lucwaba's single utterance and Fikizolo's continuous polished narration undermines Red's very own publicity that it is 'told through the voices of the people involved.' Moreover, although viewers will not know this, we are missing the voices of two of the main protagonists of the events of 1990 at the Mercedes plant who are no longer alive: Mthuthuzeli Tom and Ludwe Bakaco. Appearing as opposing parties in the conflict that emerged at MBSA among the workers over the strategy of centralised bargaining across the motor car industry, their involvement is invoked through Fikizolo, who is clearly Tom's ally. 'Through whose voices are we hearing and seeing the events?' is the nagging question in Red.

This is an important point not only for the depiction of past events but, also, as we are continually reminded in Red, for what was at stake in them. At the very core was the right to speak on behalf of workers at Mercedes in 1990. Could NUMSA negotiate on behalf of workers at the plant in a centralised bargaining structure across the motor industry? In effect Red brings together two meanings of representation. One is of symbolism, meaning, visual strategies, juxtapositions, silences and so on. ${ }^{3}$ The other appears as the ability and authority to re-present views of an individual or an

1 See Miriam Daepp interview with Simon Gush, 'The Red Mercedes-Benz', Goethe Institute, Johannesburg, March 2014, http:// www.goethe.de/ins/za/en/joh/kul/mag/bku/12539289.html, accessed 10 July 2015: 'most had to be left out of the cut because we don't have enough time.'

2 Goethe Institute Calendar of Events, 'Red film screening, 17.05.2014', http://www.goethe.de/ins/za/en/joh/ver.cfm?fuseaction= events.detail\&event_id=12708997, accessed 10 February 2016.

3 See C. Kratz, 'Red Textures and the Work of Juxtaposition', Kronos 2016 (this issue). 
assemblage such as 'the workers', 'the community', 'the people. What happens in Red is that this questioning of the authority to represent leads to a tragic ending when the striking workers are fired, where we are left asking about both the political strategies in a past that we may call history, and its contemporary depiction in its assemblage as an installation entitled Red.

I want to use this double sense of representation that Red employs to consider how the voice of the worker has been deployed in the production of South African labour histories. I do this through examining what was arguably the major labour history publication in South Africa in the 1970s and 1980s, the South African Labour Bulletin. It devoted a large part of its November 1990 issue to the events at the Mercedes-Benz plant in East London in 1990. I then turn to Red itself, originally exhibited in 2014 at the Goethe Institute in Johannesburg and the following year at the National Festival of the Arts in Grahamstown and at the Ann Bryant Gallery in East London. In Red the events were made into history through voices and images on film and the fabrication of artefacts for display: 'strike uniforms', a 'Mandela car' and 'sleep-in strike beds' (which Lucwaba had alluded to). ${ }^{4}$ The latter are presented in the installation's publicity as imaginary, 'not necessarily historically accurate', counterposed with the interviews in the film component, depicted as 'the voices of the people involved' from management and labour. Instead I see the interviews on film, much like the artefacts created, as 'speculative reconstructions. ${ }^{5}$ Linking this to the spatialising technologies of museums I examine how two institutions that have emerged post-1994 in South Africa, the Lwandle Migrant Labour Museum in Cape Town and the Workers Museum in Johannesburg, evoke 'voice' and 'words' in their depictions of migrant labour. Locating both the Labour Bulletin and these museums alongside Red suggests how one can begin to 'imagine the possibilities' of how words can be appropriated to reconfigure time, memories and pasts 'for alternative ideas of [historical] production.' ${ }^{6}$

\section{Constructing History: A labour bulletin}

As Simon Gush told Miriam Daepp in 2014, the idea for the installation Red began in 2011. This was some twenty-one years after the events it sought to create associations with. ${ }^{7}$ But what happens if a history as events past is barely in place, and the story to be told is of an anticipated or desired future? What stories are narrated then and how are voices made to be heard?

This was the case when the South African Labour Bulletin at the end of 1990 decided to run a special feature on what had happened in East London over the previous few months. As the introductory note to the issue stated:

\footnotetext{
S. Gush, 'Portfolio: Red', http://www.simongush.net/red-2/, accessed 7 February 2015.

When I originally located these quotations on the publicity material for Red they were on the web page, http://www.simongush. net/red-2/. They are no longer there but can be found on the Goethe Institute South Africa Events Facebook page, 'Red by Simon Gush, 27.03.2014-16.05.2014'. https://www.facebook.com/events/468506466582724/, accessed 10 July 2015.

Goethe Institute South Africa Events Facebook page, 'Red by Simon Gush'.

Daepp interview with Gush.
} 
It was the most high profile strike of the year: workers striking against their union's policy of centralised bargaining, the biggest German investor in SA threatening to leave, the ANC (African National Congress), SACP (South African Communist Party), NUMSA (National Union of Metalworkers of South Africa) and the company lining up together in opposition to the demands of the strikers. ${ }^{8}$

The hope it expressed was that the Bulletin's coverage would draw in different perspectives, 'do justice to the complexity' and draw out 'clear lessons.' The past it sought to elicit was one that would explicitly link to an activist future derived from these lessons learnt.

The historian Nicky Rousseau has termed this approach history-as-lesson, inscribing a past into a usable history where 'past, present and the future are tied together in a continuous inextricable chain'. What she calls the 'pastness of the past' is ignored, history is turned into 'a neat and bloodless fit' and any 'misfits and lapses' becomes mistakes to be learnt from. ${ }^{10}$ History-as-lesson has been key to the Labour Bulletin since its inception in 1974. Initially published by the Institute for Industrial Education in Durban, it was associated with and supported a growing emerging independent trade union movement in South Africa. ${ }^{11}$ In order to provide this service, the journal published historical accounts of labour movements in South Africa and internationally, news about contemporary labour organisation and issues, and was a vehicle for debates about strategies that the emerging unions could employ. Its editorial policy, as it developed over the years, was to encourage 'constructive criticism' of trade unions but it would not publish articles that the editors judged to be of a 'sectarian nature' and which could have 'a divisive effect on the labour movement.' ${ }^{12}$

The history lessons that the Labour Bulletin articulated drew substantially on, and in several cases affirmed, relationships of education and research between labour activism and the academy. Binding the two was what Munslow and Jenkins have called a constructivist genre of history. Rather than positing history as mode of reconstructing the past emerging from discovery and recovery of an archival presence - all of this takes positivism as its most extreme form - constructivist historians articulate a conceptual or theoretical approach. Empiricism is not enough. Instead, establishing truths takes place 'precisely because history is constructed through using the tools of sophisticated conceptualisation and social theory. ${ }^{13}$ In the case of South African labour history from the 1970s, the prime organising category was one of class, reflecting 'the ... school of radical South African history', and deployed to discover formal

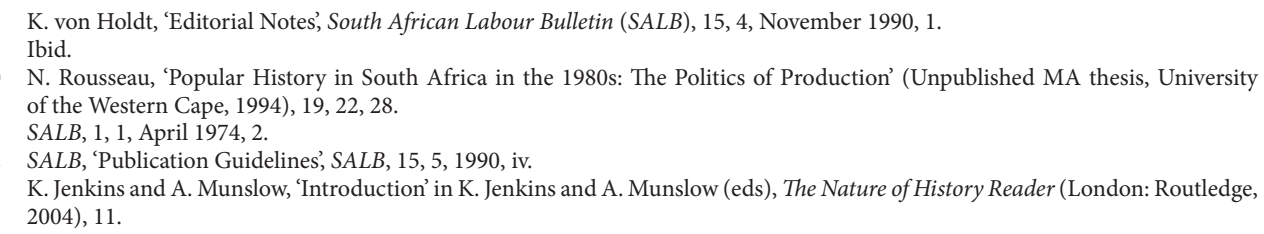


and informal structures of organisation in the workplace and in society at large. ${ }^{14} \mathrm{On}$ foundations constructed by articulating theory and then made verifiable through evidence, labour history established itself 'firmly inside the university' and as 'a product of and a service to' the renewed worker action of the 1970s. ${ }^{15}$

According to Eddie Webster the historiography that emerged in this confluence of activism and the academy pursued themes of labour supply, the role of ethnically designated reserves 'in limiting the cost of reproduction of labour power', how the 'colour bar' was a mechanism of exploitation and, more generally - referring to Frederick Johnstone's work ${ }^{16}$ - how racial discrimination emerged out of 'the structural conditions of South Africa's economy. ${ }^{17}$ From these accounts two interrelated issues were, from early on, identified as key to the emerging trade union movement: the role of the segregationist and then apartheid state in suppressing labour militancy, and the racially divided working class that was evident in the ways trade unions were structured. Webster's collection of essays from the early days of the South African Labour Bulletin, published in 1978, dealt precisely with these issues: the ways the state had incorporated trade unions in the past, how worker consciousness and militancy had and could emerge outside the bounds of formalised structures, and the possibilities of nonracial, militant labour organisations arising out of changing forms of industrialisation. From these, history lessons emerged about the relations between the new unregistered militant labour movement of the 1970s and pre-existing registered, racially designated passive trade unions, and the possibility or otherwise of an organised nonracial aggressive democratic worker movement coming into being.

My own research and writing was heavily influenced by this approach to history as lesson as I investigated these themes in relation to the emergence of the Garment Workers Union (GWU) on the Witwatersrand under the leadership of its general secretary Solly Sachs in the first half of the twentieth century. I focused in particular on worker-leader relationships and related this to the role of the workers and the union in the wider political struggle. My emphasis on the GWU corresponded to intense debates that were taking place in the 1980s 'around the internal structure' of emergent trade unions and the role of 'workers and trade unions ... in the transformation of South African society'. The GWU of the 1930s and 1940s was specifically cited as an example of how the new unions could pursue a strategy of registration under the reformed labour legislation of the apartheid state in the 1980s and retain their militancy and commitment to the workers' struggles. ${ }^{18}$ Along with the Food and Canning Workers Union and the Textile Workers Union the GWU 'mounted serious campaigns against the racially discriminatory provisions and bureaucratic

14 E. Webster, 'Ten Years of the South African Labour Bulletin' in J. Maree (ed), The Independent Trade Unions 1974-1984 (Johannesburg: Ravan, 1987), xiii.

15 E. Webster, 'Labour History in Southern Africa' in E. Webster (ed), Essays in Southern African Labour History (Johannesburg: Ravan, 1978), 2-3.

16 F.A. Johnstone, Class, Race and Gold: A Study of Class Relations and Racial Discrimination in South Africa (London: Routledge, 1976). In a similar vein see R.H. Davies, Capital State and White Labour in South Africa 1900-1960: An Historical Materialist Analysis of Class Formation and Class Relations (Brighton: Harvester, 1979).

17 Webster, 'Labour History', 2-3.

18 L. Witz, 'Servant of the Workers: Solly Sachs and the Garment Workers Union, 1928-1952' (Unpublished MA thesis, University of the Witwatersrand, 1984), vi. 
controls contained in the IC (Industrial Conciliation) Act, while at the same time taking advantage of being part of a formalised bargaining structure. ${ }^{19}$ My response to citing the GWU as a history lesson, or what Fine, De Clercq and Innes described as an inheritance, a 'legacy of history', ${ }^{20}$ was ambivalent. On the one hand each situation had to be 'analysed in its context at a particular historical juncture', but once this had been accomplished one could 'extract pointers for the directions of contemporary trade unions.' ${ }^{21}$

The Mercedes-Benz strike in 1990, some ten years after the intense debate over registration (see below), was a challenge for the Labour Bulletin precisely because of the stark divisions on the shop floor and how these appeared to have serious ramifications for the future of a trade union movement that claimed to strive for a future of class solidarity across industries and more broadly, nationally and internationally. At stake was whether the trade union could represent workers' demands across the board at a national level. The dispute also appeared to revive older tensions that had come to the fore in the registration debate of the early 1980s between the unions that sought to emphasise shop floor organisation, such as those affiliated to the Federation of South African Trade Unions (who favoured registration) and those who sought to give priority to broader community or worker alliances, such as the South African Allied Workers Union (and who had largely argued to boycott the new labour structures of the 1980s), which had developed a strong base of popular support in East London and on the shop floor in the 1980s. ${ }^{22}$ How could a 'dispute that sent shock waves through the labour movement ${ }^{23}$ and gave the impression of opening up old wounds be turned into words while not being sectarian?

This was done in four ways. The first was to resort to a strategy of magnitude: this remains the largest number of pages devoted by the journal to a dispute in a single factory (30 out of 85 pages in the issue). ${ }^{24}$ Secondly, the Bulletin presented a perspective that what was being reported was a 'real story' on the strength of firsthand testimony. So, from the Bulletin's headquarters a special investigative team was sent to East London where they 'spent hours interviewing shop stewards, union officials and management. ${ }^{25}$ Extracts from the interviews were then assembled into a series of articles on aspects of the strike: 'Mercedes-Benz and NUMSA: No Easy Drive to National Bargaining'; 'Divisions and "Factory Tribalism;"' 'The Mercedes-Benz Strike: A Glimpse into Our Future'; 'A Decade of Struggle at Mercedes'; “'Our Factory

19 B. Fine, F. de Clercq and D. Innes, 'Trade unions and the State: The Question of Legality', SALB, 7, 1 \& 2, $1981,44$.

20 Ibid.

21 Witz, 'Servant of the Workers', vi. I noted that the GWU largely accepted parallel racially designated trade unions. See L. Witz, 'Separation for Unity: The Garment Workers Union and the South African Clothing Workers Union 1928 to 1936', Social Dynamics, 14, 1, 1988, 34-45; L. Witz, 'Support or Control? The Children of the Garment Workers' Union' in A. Mabin (ed), Organisation and Economic Change, (Johannesburg: Ravan, 1989), 120-145.

22 These tensions were expressed in a series of responses to Fine, De Clercq and Innes in the following issue of the SALB. See General Workers Union, 'Response to Fine, De Clercq and Innes', 16-25; F. Haysom, 'In Search of Concessions: Reply to Fine et al'; 26-41; A. Hirsch and M. Nicol, 'Trade Unions and the State: A Response', 42. All in SALB, 7, 3, 1981. On the emergence and growth of SAAWU see J. Maree, 'SAAWU in the East London Area: 1979-1981' in Maree, Independent Trade Unions, 31-43.

23 Forrest, Metal That Will Not Bend: National Union of Metalworkers of South Africa 1980-1995 (Johannesburg: Wits University Press, 2011), 197.

24 Ibid.

25 'Editorial notes', SALB, 15, 4, 1990, 1. 


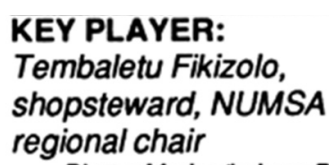

Photo: Morice/Labour Bulletin

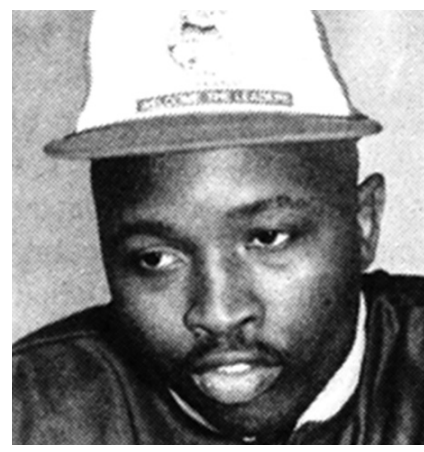

KEY PLAYER: Christoph Köpke, appointed to rescue a 'dead' company Photo: Morice/Labour Bulletin
KEY PLAYER:

Ludwe Bakaco, spokesperson for strikers Photo: Morice/Labour Bulletin
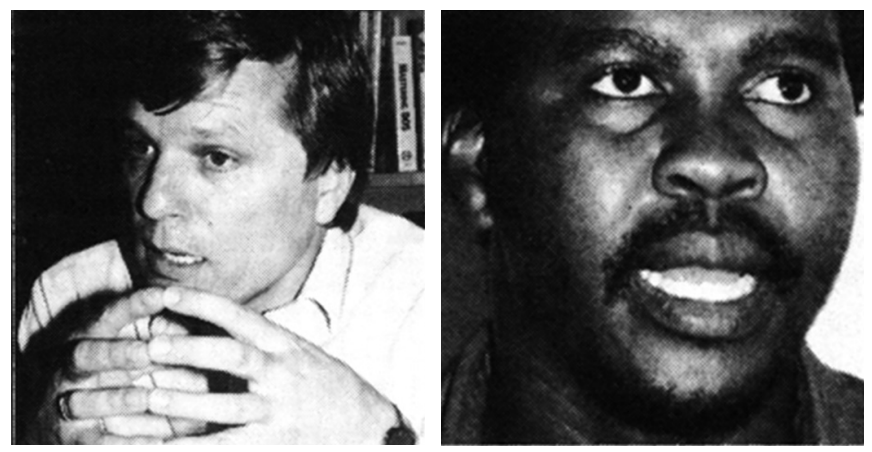

Figure 1: Key players. South African Labour Bulletin, 15, 4, November 1990. Photos: Maurice Smithers, courtesy of South African Labour Bulletin

Has Been under Worker Control since 1987" Says MBSA Head'. Thirdly, words in these articles are always set against each other. Statements from Fikizolo and Tom, on the one hand, are countered by those of Bakaco. Finally, images of people identified as 'key players' are interspersed through the various articles. These are in the form of small passport-type photographs usually of the individual's face. In addition to being identified by name and captioned as a 'key player', these photographs sometimes include a designation to position the speaker who was being cited in a representative capacity: 'veteran shopsteward', 'seasoned auto organiser,' 'shopsteward NUMSA', 'spokesperson for strikers'. Alternatively, a selected quotation from what they had said substituted for a designation as if they were either well known or their words would speak for themselves. So for Christoph Köpke the caption reads, 'appointed to rescue a "dead" company', and for Moses Mayekiso, 'the union will have to investigate whether there are valid grievances. The captions attached to the photographs, either as specific designation or as a small selection from the interview, indicate the claim of the Bulletin not just to be depicting many, but also a variety, of representative voices.

The words from those identified as key players, their photographs and the analysis provided by the Bulletin's editor are all set alongside another series of photographs. Drawn from contemporary newspapers, the Bulletin's photographer Maurice Smithers and the Afrapix photographic collective, these are used to provide context, depict events and then illustrate consequences. The site for the stories is established through a generic scene of autoworkers at work in an unidentified factory; the empty East London dockyard is a signifier of economic depression; and a factory is identified as a supplier of automotive components which had to retrench workers. The events of the photographs are of a worker demonstration with a banner reading 'Zimbinda ba eMBSA sifuna iR3 namhlanje' ('Bad news for MBSA, we want R3 today'); a scene of workers sitting languidly in what is identified as a home in Mdantsane 'waiting 


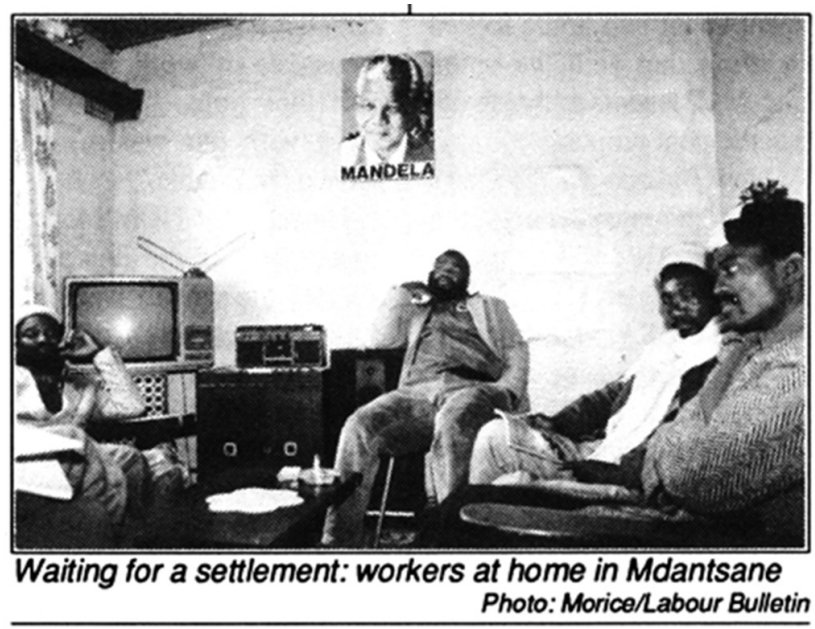

Figure 2: Waiting for a settlement: Workers at home in Mdantsane. South African Labour Bulletin, 15, 4, November 1990. Photo: Maurice Smithers, courtesy of South African Labour Bulletin

for settlement'; a mass meeting of MBSA workers about to be addressed by Moses Mayekiso, Joe Slovo and Wilton Mkwayi; and a close up of two people leaning on each other and looking with deep intent (perhaps at the same meeting) and captioned, 'MBSA workers listen to their union and political leaders'. Finally, the results of the strike are encapsulated in two newspaper images of police vehicles moving in to remove workers from the factory and then of the 'expensive beds' made from the seats that had been used in the sleep-in. In this illustrative mode these photographs come to constitute a visual narrative that can be tracked alongside the words. Together they constitute a linear trajectory of history that provides a reconstruction of what Lalu has termed 'the event of history', defining the boundaries of both what can be said and what cannot be said. ${ }^{26}$ This event then serves a didactic purpose, enabling the Bulletin to link the past and present of the strike into 'a glimpse into our future.27

In this history as lesson there was a term that was written about as a spectre of a future that had emerged and was to be avoided: 'factory tribalism. From reading the Labour Bulletin it is not always clear what this refers to. It sometimes implies 'narrow plant and company consciousness among workers', which NUMSA had identified as one of the biggest dangers facing the union..$^{28}$ But it also refers to divisions within the factory between supporters of different trade unions, NUMSA and SAAWU. Both meanings of 'factory tribalism', though, were the antithesis of a trajectory of history as the making of class consciousness. Karl von Holdt, the Bulletin's editor, maintained that, while a 'developed class consciousness' was 'not a precondition for establishing centralised bargaining', centralised bargaining provided 'a terrain on which workers 
consciousness of, and involvement in, broader social and economic issues' could 'develop. ${ }^{29}$ In what Scott calls 'the time of anticipation', these words are not one of history as betrayal but of a history that needs to make time synchronous and authentic. ${ }^{30}$ In a cumulative and progressive trajectory of history, tribe as the $\mathrm{t}$-word is of a history that evokes a time long past and of division that is to be struggled against in order to achieve 'the consoling sense of temporal concordance. ${ }^{31}$

In this battle against recurring pasts the actions of those involved in the sleep-in appeared against history as a linear progression. This is articulated in the words of Thembalethu Fikizolo who in the pages of the Labour Bulletin in 1990 appears much more strident than when he is the central character in the film Red some twenty years later: 'Fikizolo believes some shop stewards inflamed the situation ... A phrase going around the factory was "Let's pour petrol on the flames!" - an example of "immature militancy;"' 'Workers were wild,' said Fikizolo; 'Objections were stifled with chanting and whistling,' according to Fikizolo; 'Workers were using abusive language and howling down opposition'; 'our view was that the workers were innocent. They were being misled by a view. For Fikizolo the leaders of the sleep-in were (in 1990) an unrepresentative, backward, out-of-control group of agitators. ${ }^{32}$

Fikizolo's words echo a press statement on the sleep-in issued on 5 September 1990 by the Ciskei Council of State, a tribal authority set up by the apartheid state. The statement refers to a 'totally undisciplined rag tag of people acting in defiance of their own union.' 'This unprecedented, chaotic usurpation of a union's right to negotiate for its members, was organised by a small group of rowdies', the statement asserts. 'Nowhere in the world can behaviour of this kind be tolerated. The foolish, and misguided element who noisily supported the occupation of the plant, should not doubt the seriousness of their folly'. It refers to the 'rogue workers of MercedesBenz', questions the sanity of what it calls a 'handful of irresponsible workers' who were crude, selfish and affected by a 'disease of pure greed'. The Ciskei Council of State was placing itself on the side of progress, modernity and economic stability (through the presence of Mercedes) and speaking on behalf of the interests of the 'local community. ${ }^{33}$

Yet is was precisely the modernity of apartheid development and its ethnically designated homelands as peripheral locations where wages were kept low, trade unions had no rights and unemployment was high that the Labour Bulletin saw as the threat to a future post-apartheid story of solidarity. The Mercedes workers were 'a highly paid minority' compared to the situation that prevailed 'less than a 100 kilometres away, in Fort Jackson and Dimbaza in the Ciskei. A possible trajectory of the story of the sleep-in for a 'future democratic SA' was the development of 'a labour aristocracy'. Not only was the Labour Bulletin making a bid on reality through its

\footnotetext{
Von Holdt, 'Mercedes-Benz Crisis', 35.

D. Scott, Omens of Adversity (Durham and London: Duke University Press, 2014), 2.

Ibid, 2, 5-6.

K. von Holdt, 'Mercedes-Benz and NUMSA: No Easy Drive to National Bargaining', SALB, 15, 4, 1990, 18-20.

33 'Comment on the situation at the Mercedes-Benz plant at East London defining the perception of the Ciskei Council of State', 5 September 1990. University of the Witwatersrand, Historical Papers, Hartford Papers, AH2960, Box3. See also South Africa Press Association report, 'Ciskei Govt in Attack on Strikers', Business Day, 6 September 1990.
} 
research and construction of history but it was projecting it into a possible future: 'Will workers such as those at MBSA be prepared to make sacrifices so that their comrades in Dimbaza - both employed and unemployed - can benefit?' the Bulletin's editor asks with a hint of rhetoric. ${ }^{34}$

In the end it was this depiction of the strikers at Mercedes as possibly becoming a labour aristocracy, where the future was being directly linked to the past of the sleepin at the MBSA plant, that was the cause of a minor controversy. Instead of seeing the strikers as an elite-in-formation, Joe Kelly, a member of the Workers Organisation for Socialist Action, felt that they were displaying confidence, militancy and struggling for basic demands. The lesson of struggle that the Bulletin was trying to construct from its history was not one that accorded with what Kelly called 'self-emancipation. ${ }^{35}$ Von Holdt's response, as editor of the Bulletin, was to de-link the possible future from the events that had taken place. He claimed that he was not saying the strikers were an elite but that there was a potential of them becoming one in a post-apartheid South Africa. Moreover, he asserted, the analysis that the Bulletin was pursuing was one that sought an in-depth understanding and was not an 'unthinking celebration of any kind of militancy.36 Relying since the 1980s more on in-house research and a strategy of making the text readable and visually attractive, the Labour Bulletin was concerned to stitch voices and images together to give workers as coherent account as possible of what happened. ${ }^{37}$ This research and presentation approach would be the journal's basis for assessing actions and considering future directions. The past was still very much tied to a future of the present but it was through verifiable research that the Bulletin placed itself on the side of history, both as a methodological practice sustaining theoretical construction of the analysis and as an envisaged future that would 'lay the foundations for a transition to socialism..38

One way to think about the way the Labour Bulletin presented its almost contemporaneous account of the sleep-in at Mercedes (and Von Holdt's response to Kelly's letter) is to see it as part of a move towards a form of labour history that, while emphasising class struggle, did not always project its outcome as utopian, inevitable and driven by structural forces of the state and capital. Instead chaos, disorder and contestation are key elements in later accounts of militant trade unionism. ${ }^{39}$ Yet the narrative genre of these labour histories that have been produced since 2000 remains that of constructivism, where experience comes to stand in for social structure, and oral histories provide the evidence to substantiate that experience. Drawing on the English social historian E.P. Thompson, Buhlungu, for instance, asserts that 'the

4 Von Holdt, 'Mercedes-Benz Crisis', 34.

Letter from Joe Kelly, WOSA, to the $S A L B, 15$, 5, January 1991, 2.

K. von Holdt, 'Von Holdt Responds to Kelly', SALB, 15, 5, January 1991, 3.

7 J. Maree, 'Against the Odds: The Sustainability of the South African Labour Bulletin', Transformation: Critical Perspectives on Southern Africa, 72/3, 2010, 56.

38 Von Holdt, 'Von Holdt Responds', 3.

39 Karl von Holdt's Transition from Below: Forging Trade Unionism and Workplace Change in South Africa (Pietermaritzburg: University of Natal Press, 2003), which deals with NUMSA and the forms of workplace reorganisation at Highveld Steel at the time of South Africa's democratic transition in the 1990s, typifies these histories. See also S. Buhlungu, 'The Rise and Decline of the Democratic Organizational Culture in the South African Labor Movement, 1973 to 2000', Labor Studies Journal, 34,1, March 2009, 91-111 for a similar approach in his account of the strike against NUMSA at the VW plant. 
adoption of new doctrines should rather be conceived of as a dialectical blending of intellectual influences and the social idioms and lived experiences of workingclass people. ${ }^{40}$ Although processes and outcomes appear as fluid, mobile and contested, it is the working classes as a given social category that constantly remain in place to make history. As Scott points out in her critique of Thompson, it is through the strategic displacement of structure and the narrative generation of experiences that 'the ontological foundation of working-class identity, politics, and history' are established. ${ }^{41}$

The only other extensive account of the sleep-in at Mercedes (in Kally Forrest's history of NUMSA, published in 2011) makes similar claims to represent worker experience 'from their point of view.' 'Their' in this case appears to be that of the workers becoming members of a trade union that is depicted as a powerful force 'for creativity and emancipation. ${ }^{42}$ What the Mercedes-Benz sleep-in did, of course, was disrupt this convergence and question the liberatory potential of the union as representative of worker interests. Forrest draws heavily on the articles in the November 1990 issue of the Labour Bulletin to explain this divergence and presents the sleepin as an 'eruption of "factory tribalism," where accounts of NUMSA officials tell of emotions replacing substantive issues and 'heavy intimidation' is the order of the day. ${ }^{43}$ Forrest's analysis is much more sympathetic than some of the accounts she cites, as she points to the difficulties and confusion among workers in a moment of political transition from an anti-capitalist rhetoric to one of 'co-determination' with industry, and from plant-level to industry-wide bargaining. But in the end the story she tells of the strike at Mercedes is one of ill-discipline, where 'dissident shop stewards' made mistakes and 'the limits of directionless worker control' were exposed. ${ }^{44}$ Yet out of this there are the lessons for NUMSA: to be alert to worker grievances; to tread with circumspection and delicacy in moments of transition; and, in the words of Mthuthuzeli Tom, who is cited by Forrest, 'to 'balance politics and material interests. ${ }^{35}$ Worker experience is thus the evidence for constructing history-as-lesson for a future of solidarity.

\section{Speculative Reconstructions: Red}

At the beginning of the workshop 'Red Assembly' in August 2015, the artist Simon Gush, whose work of installation art, Red, was an inspiration and focal point for the gathering, was in a staged conversation with one of the workshop's organisers, Helena Pohlandt-McCormick. Their discussion commenced with beginnings: what led Simon to think about creating a work of art that revolved around the simultaneity of a strike at the Mercedes-Benz plant in East London in 1990 and the construction of

\footnotetext{
0 Buhlungu, 'Rise and Decline', 107.

J.W. Scott, 'The Evidence of Experience', Critical Inquiry, 17, 4, Summer, 1991, 785.

Forrest, Metal, 2-3. Italics are in the original.

Ibid, 194-5.

Ibid, 199.

Ibid. Italics in original.
} 
a red W126 S-Class Mercedes-Benz for the recently released ANC (African National Congress) leader Nelson Mandela on the initiative of the workers that year? Gush initially referred to hearing stories about the strike from his father. But what further piqued his interest was finding an issue of the South African Labour Bulletin where its front cover headlined the Mercedes-Benz sleep-in. ${ }^{46}$

Listening to Gush's tale of the making of the exhibition, and after carefully watching the film Red before the workshop, I was a little surprised. How had I not realised that the material in the Labour Bulletin had been so fundamental to starting the project? I had not seen it mentioned at all in publicity on the artwork in its previous incarnations in Johannesburg and Grahamstown. I had somewhat naively assumed that Gush had either ignored or not located the Bulletin. Relatedly, and presumably why I missed the link, there was a real dissimilarity between the renditions and reconstructions in Red and in the Labour Bulletin. Of course one was almost contemporaneous and the other nearly a quarter of a century after the events. Some of the people spoken to were also different, although there were some significant overlaps. But most importantly there was a distinct difference in approach. Instead of constructing a narrative from which lessons could be learnt, Gush found it was the ill-fitting combination of strike and gift (to Mandela) that gripped him: 'I was interested in them both as stories that couldn't find a conclusion. ${ }^{\text {.47 }}$

Yet the publicity material's claim of using voice to convey intimacy with the events as history appears to invite narrative closure. While voices have been used in history to assert processes of recovery and correction beyond the written archive, at the same time they have been turned into words that legitimate forms of authority, be they colonial, nationalist or postcolonial regimes or in some cases scholarly practices. According to Cohen et al, 'the African "voice" - cradled, massaged, liberated, and authenticated within the expert approaches of the African historian - comes to represent (or at least represents the opportunity to reach for) truth while it bolsters scholarly claims to objectivity'. The voice performs the dual role of 'speaking from' and 'speaking for', with an appearance of democratic sensibilities sustaining claims 'to be more authentic, and thus more objective'. ${ }^{48}$

Although Gush found that the Bulletin contained an extensive account of the strike, there was very little on the parallel event that interested him, the construction by the workers of the Mercedes for Mandela. Its only mention was tucked away in an interview that the Bulletin conducted with Christoph Köpke, chairperson of MBSA at the time, and Ian Russell, the company's human resources manager. ${ }^{49}$ According to Gush, in his exchange with Pohlandt-McCormick, it became evident that in order to find additional information, establish some form of veracity and seek a greater diversity of perspectives, more research was required. Unable to find this in articles

\footnotetext{
46 Simon Gush in discussion with Helena Pohlandt-McCormick, 'Red Assembly: Time and Work Conference', Ann Bryant Gallery, East London, 27 August 2015.

47 Daepp interview with Gush.

48 D.W. Cohen, S. Miescher and L. White, 'Voices, Words and African history' in L. White, S. Miescher and D.W. Cohen (eds), African Words, African Voices: Critical Practices in Oral History (Bloomington: Indiana University Press, 2001), 3-4, 15.

Karl von Holdt, interview with Christoph Köpke and Ian Russell, SALB, 15, 4, November 1990, 38-44.
} 
and documents, it was 'speaking to people' through a variety of connections largely made by Ian Russell that Gush used to establish a concurrence of the workers' gift to Mandela and the strike that was produced in Red..$^{50}$

Gush's account of the research process for Red and in particular how the film was made seems to approach history in a very conservative way, with the accounts given by those interviewed seeming to provide a basis for a reconstruction of events past. Yet in the part of the display that deals with the production of tactile objects the red Mercedes, the strike uniforms and the sleep-in beds - the reconstruction is described in the publicity as 'speculative. That dual mode appears anomalous, where reconstruction constantly refers back to evidence to authenticate a narrative as history, while speculation implies some form of guesswork or taking a chance based upon probabilities, where foundations are far less sure. But, as Paige Sweet shows, by bringing them together through the objects that are aesthetic pieces and have no 'use value, the very idea of history as reconstruction is brought into question. Although referring back to events, in their appearance the 'strike uniforms' and 'beds' created for Red do not approximate either to the apparel of the strikers or the sleeping arrangements during the strike. Instead, what they do is 'cast doubt on historical artefacts mobilized to support a particular version of events and to query forms of evidence and the construction of narratives generally. ${ }^{51}$ Similarly the disembowelled red Mercedes, without engine, seats or steering, while referencing the gift to Mandela, is resignified 'from a useful thing to a thing of aesthetic value and contemplation. ${ }^{52}$ In the move from use and commodity to objects in the art gallery, the idea of reconstruction signifies not a referral back to history as emerging from a located archival fragment but rather opens up history for speculation and reflection. The artefacts as 'speculative reconstructions' offer possibilities of divergent trajectories, and the enactment of disassembly redirects attention to 'the construction of evidence in the making of historical narrative. ${ }^{53}$

Similar speculative reconstructions are constantly called upon in the film that forms part of the installation Red. The awkwardness of history is established through a lack of fit. Pieces are not identified as representative of time, place or individual; and although they are assembled together their situatedness is queried, especially on first viewing. Most notably we actually don't know very much about who is speaking. The first words are heard from a blank dark screen that lasts for ten seconds: 'I think on the 25th of May, it must have been a Wednesday ...' And when Tembalethu Fikizolo appears and is identified by name, we are not told anything more about who he is, either in the past, or at the time the film was made. Moreover, we aren't told what he is talking about: 'What had happened, ne, there was a strike that was led by NUMSA, an illegal strike that was led by NUMSA. Okay and it started at the F-Site and you know Kronos 2016 (this issue).

51 P. Sweet, 'The Renewed Work of Copies', parallax, 22, 2, 2016, 163.

52 Ibid, 160

53 Ibid, 163. 
it moved up through all the other aspects of the plant.' Those are the opening words of Red. It is as if one is the middle of the film. When I watched it the first time I actually went back to check that I was at the beginning. Red uses a tactic very common for plots in novels where, instead of a linear unfolding of time, it is only later in the film that one can return and reflect upon the characters and their opening words. The time is one not of progression but of constant returns to earlier moments to reflect and reassess earlier judgements.

Not only do we start off by knowing very little about who is talking but there is no overall narrator to guide us. The film is just tied together by the individuals speaking, sometimes at length, and a set of breakaway images, sometimes with voice overs, sometimes to accompanying sounds from the scenes, sometimes in silence. Moreover, the scenes themselves are not of the time that is being talked about but appear as images from when the film was made, and they often have little connection to what is being spoken about. Unlike the photographs in the Labour Bulletin that are used to document a reality of what happened, the visual landscapes in Red look disconnected and somewhat arbitrary, where connections can be made but the associations are not necessarily the moving force of history. A series of incongruent images of swimming pools, street scenes, dockyards and factories are brought together with the stories being told of militancy, violence, work, a gift, exuberance, division and sadness. Without the scaffolding to hold these together, the voices and images of Red not only offer multiplicity but also the possibilities of stories of labour that move beyond 'the monolithic conventions' of 'fixed autonomous positions. ${ }^{54}$

The stories told in Red are of multiple and contradictory betrayals: workers betrayed by the union; strikers betrayed by their leaders; management betrayed by a trade union; individuals betrayed by their comrades; workers betrayed by management; and perhaps in all these the anxiety of being betrayed by history. That last betrayal is one of both the events that took place in the years after the sleep-in and also of how it is depicted. The faithfulness in re-producing all these betrayals is that they become a set of 'interdependent assemblages of hopes, fears, dreams, legacies and testaments, woven into a shared text-tile ... a textile being constantly rehabilitated. ${ }^{55}$

The only voices that don't appear to be heard in Red are those of the film makers Simon Gush and James Cairns. This has a contradictory effect. As indicated above, it means there is no omniscient narrator to lead the viewer. But the lack of an interviewer for the stories being told also eliminates conversation, leaving us with unmediated voices telling the story in the first person, singular and plural. This narration is transcribed into subtitles, which turns it into words not only to be heard but read. The stylised setting of the stories being told (the interviewers do not appear on camera) and the smooth uninterrupted narration, may give the impression of staging, performance and an elaborate stitching together of fragments. Yet they do contradict 
the spirit of incompleteness, hesitation and incongruence that is so marked throughout. Perhaps the absence of the film makers justifies the publicity for the film as one enabling the 'voices of the people involved'.

The words of Gush and Cairns do come into view at what may be called an ending of the film after 81 minutes. First we hear a final elegiac take from the local NUMSA organiser Mteteleni Tshete, who says, 'But if we have known. If we have known at the time, ja. We wouldn't be sitting here today. Maybe I would be sitting here because it's fine, but I mean the other workers maybe would still be with Mercedes-Benz. Tshete's words voice his desperation to have known history as the future. And then the film makers have the last word. Unlike the statements in the rest of the film, theirs are without sound. They are not the subtitles that accompany the audio soundtrack of the interviews throughout but appear as a white text on the black screen for just under a minute before the credits roll.

After the tumult of the 1990 plant occupation and the subsequent dismissal of just over five hundred workers, the Mercedes-Benz plant in East London entered into a period of constructive and amicable relations between workers and management that lasted twenty two years.

In that time, they managed to become one of Mercedes-Benz's best plants worldwide and have won numerous awards for excellence in automotive manufacturing.

Nelson Mandela's red 500SE is on loan to the Apartheid Museum in Johannesburg. In 2013, Mercedes-Benz workers in East London downed tools and went on strike for the first time since 1990 .

It is a powerful moment of ending with words in silence that commands the viewer's attention. These words fill in time between the past of the events narrated and a future as occurrence, where the sleep-in at the MBSA plant leads to an appearance of progress (the 'best plant worldwide') based on the 'dismissal of just over five hundred workers'. Of course such utterances do not bring history to a conclusion. Instead the 'temporality of the aftermaths of ... catastrophe $e^{56}$ is that ironically it brings in a claim of progress with 'numerous awards for excellence', and Mandela's car is consigned to the past in a museum of apartheid. Yet, at the moment the film is being made, there is a strike at Mercedes-Benz in East London. And there we are left with the words of Gush and Cairns, with an inconclusive future and past that they open up to constant speculation. 


\section{Labour Museums}

In the catalogue of Work, a résumé published by the Stevenson Gallery of Gush's work produced for the installation at the Goethe Institute in 2014, the interviews conducted for the film Red appear in a very different format. Extracted and listed under the names of the interviewees they almost come to resemble a museum display of words as texts representing an interview with an individual. Sometimes they are set alongside visual images of the factory and followed by stills of those being cited, with images of the installation. Tshete, Fikizolo, Russell and Groom as they speak in the text. In this instance, prominence is given to the sleep-in, described by Tshete as a spontaneous decision: 'it was not an organised thing, you know'. Fikizolo's words are used to tell about the situation at Mercedes-Benz in the 1980s: 'you always had strikes'. This is corroborated by Russell: 'you know they had been very successful at bringing the company to its knees'. And Groom explains the choice of the colour and model of the Mercedes for Mandela: 'let's give him something from us, you know, featuring our colours .... we wanted the best for Nelson Mandela, 500SE, top of the range. ${ }^{57}$ Instead of holding together a narrative of conflict, exuberance and tragedy, the interviews in the catalogue are used to raise themes related to the installation. If the film is 'closer to poetry than a cinema of denunciation', then the words in the catalogue are employed to sustain the images. ${ }^{58}$

A similar strategy is employed at the Lwandle Migrant Labour Museum, 40 kilometres outside Cape Town. It is one of only two museums in South Africa directly related to issues of workers, although with its emphasis on depicting the social as life, in what was formerly a migrant labour compound, there is a glaring absence of work itself. As in the series of articles in the Labour Bulletin, the spectre that looms large for the museum is one of 'tribe.' This time, though, 'tribe' is not the alternative to class but is a tourist stereotype, a 'rural timeless Africaness in an urban setting, often cast as ethnicity. ${ }^{59}$ From the start the museum struggled against the notion of an ethnically designated and situated cultural village and calls from the tourism industry for it to present Xhosa life and culture. Through the interviewing process and the curatorial interventions of transcribing, editing, translating and designing extracts from selected interviews, the museum instead assigned a range of meanings to the concept of home: sometimes as a rural space considered that of origin; at other times as the site of urban residence; or as a multiplicity of homes. Each interviewee on display in its permanent exhibition 'Stories of Home' represents one or more meanings of 'home', the intention being to subvert the idea of Lwandle as 'a designated ethnic rural space where the planners of apartheid [and the tourist industry] sought to place the migrant worker'. The individuated 'accounts of ambivalence' that the museum displays configure home as 'a site of mobility and exchange'.60

\footnotetext{
S. Gush, 'Work', Stevenson Catalogue 76 (Johannesburg: Michael Stevenson Gallery, 2014), 50-5.

H. Chávez Mac Gregor, 'Let There Be Light' in Gush, Work, 5.

N. Murray and L. Witz, Hostels, Homes, Museum (Cape Town: UCT Press, 2014), 66.

Ibid.
} 
These biographical vignettes of home in English and Xhosa are situated above, below and alongside 'big and very loud' photographs of the interviewees that take up most of the exhibition's frame. ${ }^{61}$ Through the alignments of photograph and text, the stories of home appear free of mediation. As in Red, the interviewers are invisible, and 'each story begins with the phrase "I am..." before launching on to a succinct biographical narrative of a life that tells of journeys, occupation and home.' Sometimes the image creates the impression of conversations or dialogues, although (again as in $R e d$ ) the interviewer is unseen. Waiving the interviewer enables a narrative from what appears an 'individuated source' who in turn could sound like a representative 'bearer of Lwandle's history'.62

At the Workers Museum in Newtown, Johannesburg the stories presented are similarly of journeys from the rural to the urban, and of conditions in the hostels. But, unlike those in Lwandle, they mostly appear as audiovisuals on television screens. In a re-created hostel the screens are attached to concrete bed-like structures, with excerpts from the interviews inscribed on the walls for emphasis. In the central exhibition hall the screens are accompanied by artefacts such as blankets, clothes, pass books and brooms, and full body photographs of those interviewed, with a couple of lines of text providing a biographical context. The film itself moves forward in a series of themes with headings such as rural life, making the decision, the journey, arriving at the compound, life in the city, living away from home, visiting home, and life now. The speakers talk about their life theme by theme rather than as an ongoing story. The film is deliberately staged in a studio setting and the interviewees, speaking in English or Zulu or Sotho (sometimes with subtitles), appear to be performing for the camera. Without an interviewer, presenting their individual lives in a half-lit studio featuring wooden panels, corrugated iron sheets and hanging blankets, and with background music indicating either a rural or urban African context, they speak directly for the experience of migrant workers.

Whereas in Red the interviews are interspersed with scenes and voice overs of contemporary East London, in the Workers Museum the film footage, like the accompanying music, evokes scenes of arbitrary people in rural and urban settings as depictions of a past. The unsourced film clips suggest almost idyllic rural settings of cattle, huts and valleys, of departures from home, and then of scenes in a bustling city and of the joy of return. At times these images jar alongside the spoken story and with some of the still photographs depicting scenes of violence and hardship in the compound and the pass-office; but in their anonymity the speakers reinforce a story of life as a move from 'tribe' to 'city'. As it unfolds on screen, this composite tale ends with Mandela and by implication a life that has led to betterment and progress. This is in striking contrast to Red, where the gift to Mandela is followed by the sleep-in and dismissal. 


\section{Coping with the Past}

Introducing their book Coping with Past, the editors Pasquale Gagliardi, Bruno Latour and Pedro Memelsdorff note that the key issue in the conference in 2007 concerning the production of a facsimile of Veronese's 'Wedding at Cana' in San Giorgio Maggiore in Venice was

understanding how it is technically possible to revive the past or, so to speak, 'to let the past resonate', avoiding at the same time fetishism and refusal, slavish imitation and betrayal; and how, through comparisons, the practices used in different fields ... can mutually inform and enhance each other. At a time of growing fundamentalism of all denominations, this comparative exercise could turn out to be a crucial way for understanding how we can inherit the past 'well', what it really is to re-produce and thus, perhaps, faithfully betray. ${ }^{63}$

Locating such moments of re-production is difficult within labour histories, given their determination to maintain the past as lesson and future as foretold. Contemporaneous with the sleep-in at Mercedes-Benz in 1990, the Labour Bulletin's pasts were always headed towards a horizon of unity, class consciousness and a 'utopian future' of a 'historical destiny' ${ }^{64}$ Although in later labour histories these pathways to history were always negotiated, contested and uneven, the aim was always to identify obstacles on a projected route to the future and provide ways to overcome them. Labour history at the Workers Museum in Newtown brings together two stories of progress: from rural to urban, and oppression to freedom. In Lwandle the 'creation of an institution that called itself a museum asserted the possibility of a public citizenry with a recognisable and recoverable past called history. ${ }^{65}$ The stories of home are about people becoming citizens. The developmental future, as a school pupil told the anthropologist Sean Jones in the late 1980s, was always about the dream of turning the labour compound into 'a beautiful Lwandle. ${ }^{66}$

But what happens if voices of the people involved don't convey authenticity and representivity? If instead there are storytellers who invite us to listen and view changing pasts where the future is not already written into a predetermined script? By opening up readings to flexibility, with constant reassessment of events and characters, Red imagines the possibilities of different labour histories. If representations 'are not slaves to a conventional realism' and 'fashion the conventions we use to sense ourselves in time', then the re-production of storytelling contains the possibilities of faithful betrayal: 'By releasing the present to once again re-asssemble and re-assemble

in Lwandle, 11 August 1989, cited in Sean Jones, 'Assaulting Childhood: An Ethnographic Study of Children Resident in a Western Cape Migrant Hostel Complex' (Unpublished MA thesis, University of Cape Town, 1990), 193. This quotation is used by the Lwandle Migrant Labour Museum as the title of an exhibition board that deals with the Hostels-to-Homes scheme in Lwandle in the late 1990s. 


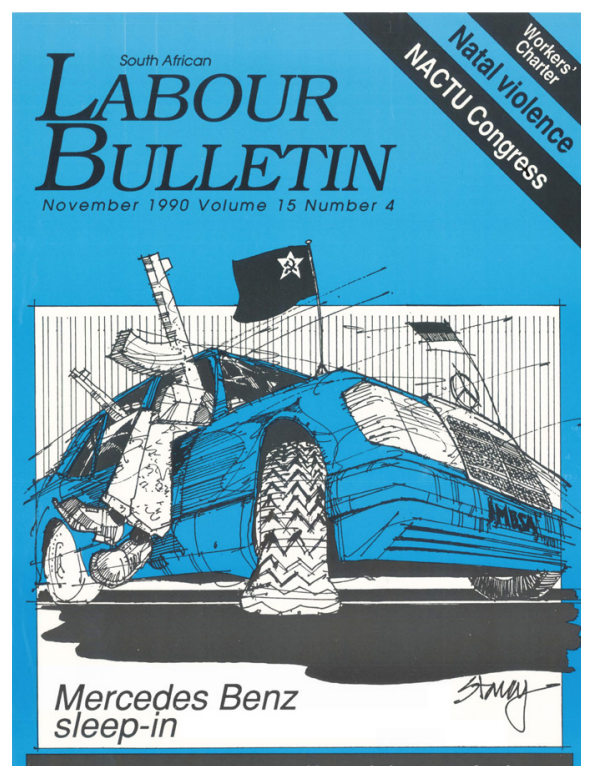

Focus on centralised bargaining
Figure 3: Front cover, South African Labour Bulletin, 15, 4, November 1990. Artwork: Jeff Stacey, courtesy of South African Labour Bulletin

the past, [speculative] representations can free the past to rejoin its vital new futures' Red is a story that gets 'us to keep changing sides, and even ... change[s] the sides' itself. In this way Red is indeed told 'through the voices of those involved', taking the us through what Powers calls 'the experience of narrative time' where 'every new event that is told' changes the 'mutable past', thereby 'altering the event that generated it'. Instead of the 'monolithic conviction' that is apparent in so much labour history, the stories in Red may be read to move us constantly backwards and forwards 'across all three tenses, through a country full of voices.' ${ }^{67}$

As a last reflection: in 1990 the Labour Bulletin had one image that opened up the possibility of multiple histories. The front cover sported a cartoon-type illustration by Jeff Stacey showing a Mercedes-Benz with a flat front tyre, flags of the ANC and the South African Communist Party on the bonnet, and AK47s and a set of legs emerging from the side windows. Repeated on the inside pages, the picture changed: the Mercedes-Benz mascot on the bonnet was replaced with one for NUMSA. While the cartoon appeared to neatly open up the narrative about worker control, forms of violence and the future of both union and Mercedes-Benz in South Africa, it can also be read ironically. Rather than seeking a future won by worker militancy or democracy, or giving direction by learning hard historical lessons (as the Bulletin was trying to do), it could be asking where this gun-toting, flag-waving Mercedes with a punctured tyre was going, if anywhere at all. ${ }^{68}$ Stacey's cartoon, it may be speculated, opened up the imaginative possibility for the making of Red twenty years later.

67 Powers, 'Saving the Best', 163-4.

68 The images that the Labour Bulletin used were a major concern for the unions. In the same issue reporting on the strike at MBSA there was a letter from the Food and Allied Workers Union saying the Bulletin had shown its logo as torn in a cartoon-like illustration in a previous issue. The union called this a 'disgusting portrayal' as it depicted disunity and fragmentation. It called on the journal to apologise - which it did, saying the image was meant to represent the view of the writer, not of the union itself. Letter from M. Madlala, assistant general secretary of FAWU, to SALB, 4; Apology to FAWU, SALB, 15, 4, 1990, 4-5. 